\title{
The Quality of Automotive Industry: The Remote Monitoring Complex of the Quality of Enterprises Activity of Company Car Service System
}

\section{Kozlovskiy V ${ }^{1 *}$, Panyukov $\mathrm{D}^{2}$, Odruzova $\mathrm{V}^{3}$, Afinogentova $\mathrm{N}^{4}$ and Ermakov $\mathrm{V}^{5}$}

${ }^{1}$ Theoretical and General Electrical Engineering Department, Samara State Technical University (Samara), Samara, Russian Federation

${ }^{2}$ Department of Modern Natural Science, Faculty of Information and Technical Services, Volga Region State University of Service (Togliatti), Samara region, Russian Federation

${ }^{3}$ Samara State Technical University (Samara), Samara, Russian Federation

${ }^{4} \mathrm{PhD}$ in Engineering, Head of the "Quality Management and Technologies in Service" department, Volga Region State University of Service (Togliatti), Russia

${ }^{5} \mathrm{PhD}$ in Engineering, Professor of the "Cars Electrical Equipment and Electro mechanics" department, Togliatti State University (Togliatti), Russia

\begin{abstract}
The development of the automotive industry is inextricably linked with the development of the ensuring operational effectiveness of the industry production sector, namely service maintenance. Today the car service is an important element at ensuring the competitiveness of products and a tool of improving the customer loyalty.

Despite the fact that there is no direct connection between the ensuring car quality in production and the quality of service in exploitation, it is obviously that the first and the second directions definitely influence on the perceived by a consumer quality of products and services and so they form an attitude of consumer community to the brand maker. That is why the measurement of service maintenance quality is equally important for automaker as the monitoring of the quality of production processes.

At the present time, in the course of solving problems on measuring quality of service maintenance, there has been found a spectrum of methods and techniques allowing to conduct quantitative (the service provider is estimated on a grade scale), qualitative (the quality of customer service is estimated by people responses) and comprehensive quantitative and qualitative researches (they include the above-described estimates).

The aim of this paper is the development and implementation of corporate service quality monitoring system with using internal information of automakers enterprises which in the future, in conjunction with results of the research of the perceived quality service maintenance, will provide the most complete quality assessment covering the corporate environment of automaker and consumer environment.

The development of information and computer technologies has had a beneficial impact on improving monitoring technologies of product and service quality. Development and implementation of information analysis algorithms of service quality allows getting a balanced assessment of consumers reflecting the quantitative and qualitative research area of satisfaction. However, the implementation of service quality researches based on data received by corporate information systems from proprietary service network enterprises to analytical quality services of automakers enterprises about the results of the maintenance and the elimination of defects and failures of cars are not widely represented in the literature, apart from a small group of sources. That is why this theme in the presented work is the main.
\end{abstract}

Keywords: Quality; Satisfaction; Service; Car; Organization

\section{Introduction}

The importance of the process organization quality of the company service maintenance of the automotive industry products has been growing over the years. There are a lot of reasons for that. Here are the main ones:

- The alignment and a gradual value decline of the initial purchase price of different brands cars at national markets and mass segments and corresponding growing role of factor possession of price for users, which include the service indicators [1];

- Active saturation of vehicle by electronics and automation systems which need periodic diagnostics and servicing in a proprietary network;

- The rigidity of policy measures from automakers to consumers which are associated with the mandatory maintenance of new cars in conditions of certified service;

- The impossibility of servicing and repairing cars on their own because of complication of the construction and integration of original components into the structure of vehicles which require the competence of staff and specialized tools at the enterprise.

\section{Methodology}

Apart from selected aspects that effect on the importance of company service maintenance, it is also should be noted the rapidly development of electric cars, cars with combined power installations and unmanned vehicles [2]. This is a new design-engineering level of auto industry which could not be provided without appropriate changes in the servicing system.

The experience shows that the most important in the management

*Corresponding author: Vladimir Kozlovskiy, Doctor of Technical Sciences, Head of the Theoretical and General Electrical Engineering Department, Samara State Technical University (Samara), 244 Molodogvardeyskaya Street, Samara, Russian Federation, Tel: +78462784311; E-mail: Kozlovskiy-76@mail.ru

Received September 22, 2016; Accepted October 06, 2016; Published October 16, 2016

Citation: Kozlovskiy V, Panyukov D, Odruzova V, Afinogentova N, Ermakov V (2016) The Quality of Automotive Industry: The Remote Monitoring Complex of the Quality of Enterprises Activity of Company Car Service System. J Biosens Bioelectron 7: 223. doi: 10.4172/2155-6210.1000223

Copyright: (c) 2016 Kozlovskiy V, et al. This is an open-access article distributed under the terms of the Creative Commons Attribution License, which permits unrestricted use, distribution, and reproduction in any medium, provided the original author and source are credited. 
Citation: Kozlovskiy V, Panyukov D, Odruzova V, Afinogentova N, Ermakov V (2016) The Quality of Automotive Industry: The Remote Monitoring Complex of the Quality of Enterprises Activity of Company Car Service System. J Biosens Bioelectron 7: 223. doi: 10.4172/21556210.1000223

Page 2 of 5

of activities of proprietary network, according to company standards, becomes the control of the customer service quality, and what is more, the control of providing the same high quality work at all enterprises is also the important aspect here without reference to the category or geographic location.

Control functions for service network of national automakers are traditionally realized through the organization of enterprises inspections on the requests of proprietary standards of work organization and customer service.

As a rule, proprietary network of automobile corporations includes hundreds of enterprises which are located that they could provide the competitive advantages to automaker. That is why it is necessary to have a significant budget for annual coverage by inspections of a whole network $[3,4]$.

In this case, it is not obvious that the organization of a large number of field inspections of enterprises of company car service center is always giving the high result which is connected with the improvement of the network as a whole. As proof of this thesis, here is presented the Table 1, where are the systematized results of legal audits of enterprises of proprietary network of one of the leaders of the Russian automotive industry for the period $2010-2013$ [5,6]. The table shows that there have been observed the same drawbacks in the different enterprises of the one proprietary network from year to year, for example, deviations in the implementation of pre-sale preparation; weaknesses in the metrological service of the enterprise; failure of existing regulations, etc. The obvious conclusion is that target audit function has been substituted for. At that time, when it is already clear that it is required to provide the system effectiveness of corrective measures, there is a growth in the number of inspections in order to identify inconsistencies [7]. So to speak: The checking is for checking (Table 1).

That is why we offer the transition from the general concept of the annual audit to the concept of remote monitoring quality of the work with the implementation of a random checks planning system by the target indicators of the service enterprises work $[8,9]$.

Of course, despite the remote monitoring of the activity, it is impossible to fully replace the auditing system. However, the significant reduction in the number of field verifications and providing at an acceptable level of information data flow about the quality of work of the service enterprises is real. Moreover, the tools implementation of remote monitoring of the quality creates the backgrounds for a much greater efficiency and for the possibility of adjusting the activities of service enterprises on the basis of identified deviations. The assumed concept also fits well into the current situation at the Russian market $[10,11]$. The constant growth of competition requires the optimization of expenses on provision of the main processes from automakers. But during the economic crisis the optimization problem becomes even more critical and often leads to a reduction in the budgets of different levels.

In such situation it is obvious that for guidance of automobile corporations it is important to maintain the conditions in which the optimization of expenses will not reduce the level of control and management of all processes in general and such an important process as the customer service, in particular. Therefore, there is the necessity of development and implementing the remote tools of monitoring of service quality which reduce the load on the automaker's budget while ensuring the quality of proprietary network management on the basis of corporate information systems linking any automaker and its service. Herewith, it is supposed that level of quality of production at the enterprise of automaker in conditions of mass production is a permanent for the whole amount of produced vehicles of a certain brand with the same release date.

An electronic implementation act of presale preparation (PP) and warranty service (WS) is the source of data for calculating the monitoring indicators, where all the main information, identified defects and service operations are fixed. Indicators, that reflect the quality of service in a particular enterprise, are calculated for the reporting period (month, quarter) and determined by assessments of deviations from the appropriative overall averages all over the whole proprietary network.

Here were considered the indicators of quality assessment on the concrete examples of monitoring of enterprises service network of one of the major automakers which are located in different geographical regions of Russia. In order not to affect the commercial interests of enterprises that participated in monitoring their names were coded, so any possible coincidences are accidental.

\section{Analysis of cointegration}

Figure 1 illustrates the diagram which shows the deviations from the average level of car defects, detectable at the stage of presale preparation for a number of service enterprises of a specific region (Figure 1)

\begin{tabular}{|c|c|c|c|c|c|c|c|c|}
\hline \multirow{2}{*}{$\begin{array}{l}\text { Identified } \\
\text { discrepancies }\end{array}$} & \multicolumn{2}{|c|}{2010} & \multicolumn{2}{|c|}{2011} & \multicolumn{2}{|r|}{2012} & \multicolumn{2}{|c|}{2013} \\
\hline & Number & $\%$ Repeatability & Number & $\%$ Repeatability & Number & $\%$ Repeatability & Number & $\%$ Repeatability \\
\hline $\begin{array}{l}\text { The lack of equipment } \\
\text { and special tools }\end{array}$ & 14 & 58 & 23 & 92 & 29 & 100 & 23 & 69 \\
\hline $\begin{array}{l}\text { Unrealized current } \\
\text { requirements }\end{array}$ & 13 & 54 & 17 & 68 & 13 & 45 & 22 & 68 \\
\hline $\begin{array}{l}\text { The elimination of } \\
\text { defects without using } \\
\text { spare parts }\end{array}$ & 9 & 37 & 15 & 60 & 20 & 68 & 21 & 67 \\
\hline $\begin{array}{l}\text { The pre-sale } \\
\text { preparation is carried } \\
\text { out with deviations } \\
\text { from the technology } \\
\text { and instructions }\end{array}$ & 18 & 81 & 14 & 56 & 11 & 38 & 20 & 66 \\
\hline $\begin{array}{l}\text { Metrological provision } \\
\text { of production does } \\
\text { not correspond } \\
\text { to the established } \\
\text { requirements }\end{array}$ & 4 & 13 & 4 & 13 & 9 & 33 & 10 & 33 \\
\hline
\end{tabular}

Table 1: The repeatability of identified deviations on the results of the inspections of enterprises of proprietary network during the period $2010-2013$. 
Citation: Kozlovskiy V, Panyukov D, Odruzova V, Afinogentova N, Ermakov V (2016) The Quality of Automotive Industry: The Remote Monitoring Complex of the Quality of Enterprises Activity of Company Car Service System. J Biosens Bioelectron 7: 223. doi: 10.4172/21556210.1000223

Page 3 of 5

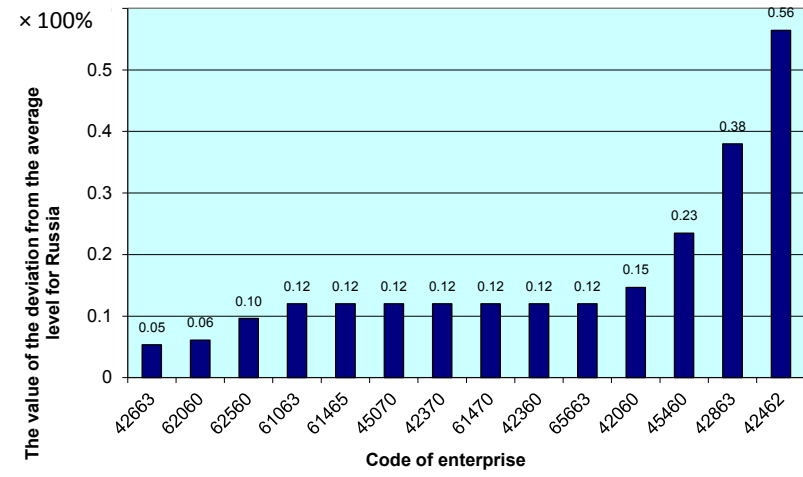

Figure 1: A diagram showing the indicator the level of car defectiveness at PP.

It can be seen from the diagram that the closest to the average statistical values at proprietary networks are the indicators at enterprises 42663,62060 . The worst ones match the enterprises 42462 , 42863. Taking into account that in conditions of mass production products of the same brand, which has been released in the same time period, should approximately have the same level of quality. And there is the question: why this level is obviously overstated at some service enterprises?

Figure 2 illustrates the diagram showing the deviations from the average statistical value of the level of costs on elimination of defects at the stage of the PP for the same regional group of service enterprises (Figure 2).

The analysis of Figure 2 shows that the greatest deviations from the average level at proprietary networks have enterprises 61063, 65663 . In this case it is seen that the service marked earlier as 42462 , is also included in the risk zone. Significant deviations from the average for considered indicator are talking about high costs for elimination identified defects that either is connected with presence of a particular uniqueness in the supply of vehicles with complex defects, but in this case the enterprise is obliged to notify the automaker, or this is a direct violation of the service standards $[12,13]$.

The diagram in Figure 3 shows the deviations from average statistical value of the level, which reflects the proportion of cars that were advertised at the stage of the PP for the same group of companies (Figure 3).

There is a clear antilider in the ranking of deviations from the analysis of Figure 3. It is the enterprise 42462 . It turns out that during the PP there appear more new defective cars than at other enterprises in the region. Of course, this raises a legitimate question about the validity of the submission of costs for elimination of defects for automakers and their acceptance.

Another interesting indicator reflecting the quality of the PP is the completeness of the list of identified defects. The indicator reflects the deviation of enterprise from the average, the established range and frequency of elimination of defects, identified at the whole network during the PP, and deviations are equally taken into account in the case of "shortage" or "overmuch" of the nomenclature of defects (Figure 4).

The analysis of Figure 4 shows that the worst indexes have enterprises 42462,42863 . They also have a significant deviation from the average indicator for Russia.

Joint analysis of Figures 1-4 shows that there is a specific group of enterprises $(42462,61063,42863)$ and there are questions to this group about the organization of process of cars pre-sale preparation. There is no doubt that data of enterprises must enter in the list of mandatory for inspection and received data should be included in the relevant work program.

Turn to the indicators that reflect the quality of the warranty service of cars on the example of other group enterprises of the same service network.

There is a diagram in Figure 5 that shows the deviation from average

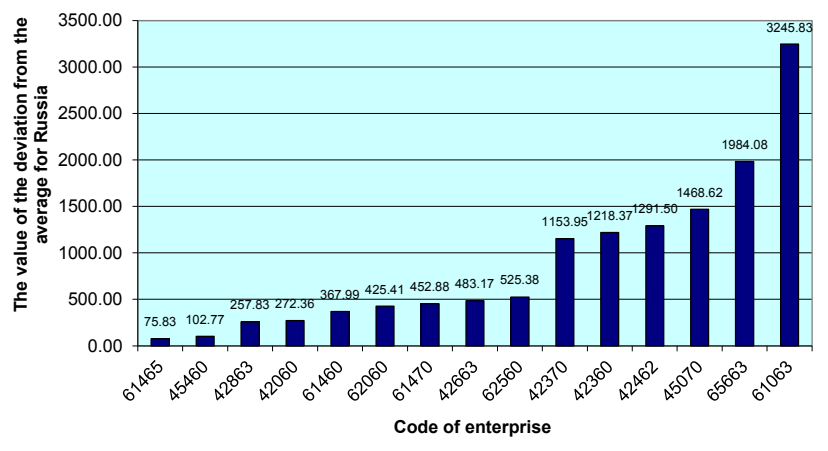

Figure 2: A diagram showing the indicator the level of costs for defect elimination at PP.

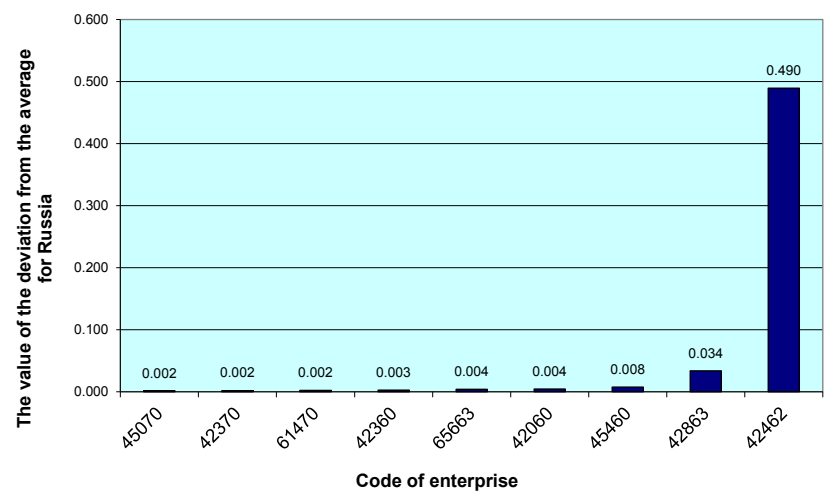

Figure 3: A diagram showing the indicator the proportion of advertised cars at PP.

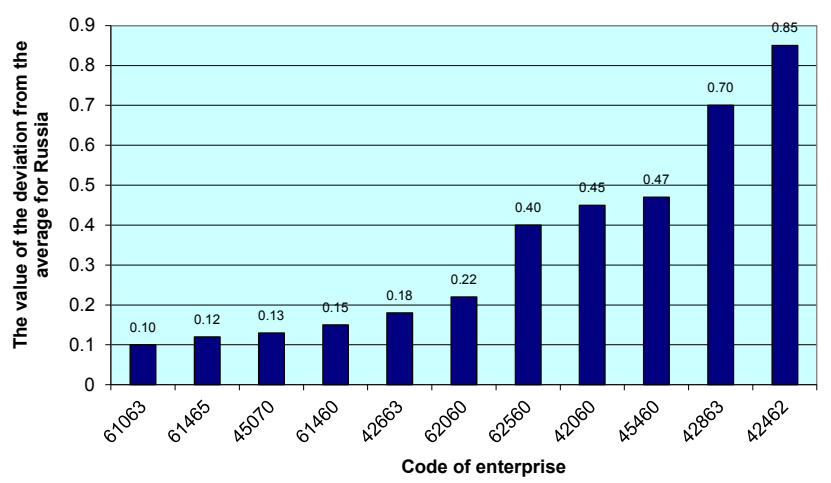

Figure 4: A diagram showing the indicator the completeness of the list of identified defects at PP. 
Citation: Kozlovskiy V, Panyukov D, Odruzova V, Afinogentova N, Ermakov V (2016) The Quality of Automotive Industry: The Remote Monitoring Complex of the Quality of Enterprises Activity of Company Car Service System. J Biosens Bioelectron 7: 223. doi: 10.4172/21556210.1000223

Page 4 of 5

values of level of car defectiveness at the proprietary network during the warranty maintenance period (WM) for a group of enterprises (Figure 5).

Analysis of Figure 5 shows that the greatest deviations from the average values of indicator in Russia have enterprises 35708, 35504, 41402. That says that at these enterprises are fixed more warranty defects than at the national average. So it raises doubts in their justifications due to the above indicated factors of stability of product quality.

The diagram in Figure 6 shows the deviation from the national average, the level of costs for the elimination of car defects during the period of WM (Figure 6).

Analysis of Figure 6 shows that enterprises 34702 and 35563 are characterized by clearly excessive level of costs for the elimination of WM defects. Moreover, the enterprise 35708, which was selected at a previous evaluation step during the considering cost index, is also included in the risk zone.

The next indicator of the quality of the WM is the completeness of the list of removable defects at the enterprises during analyzed period (Figure 7). The indicator reflects the deviation of the enterprises in the nomenclature and rate of elimination of defects from the existing relevant indicators at the proprietary network in a whole.

Analyzing Figure 7 there can be selected two enterprises with significant deviations - 35708, 35504. Moreover, enterprise 35708 appears in all previous assessments as a clear antilider.

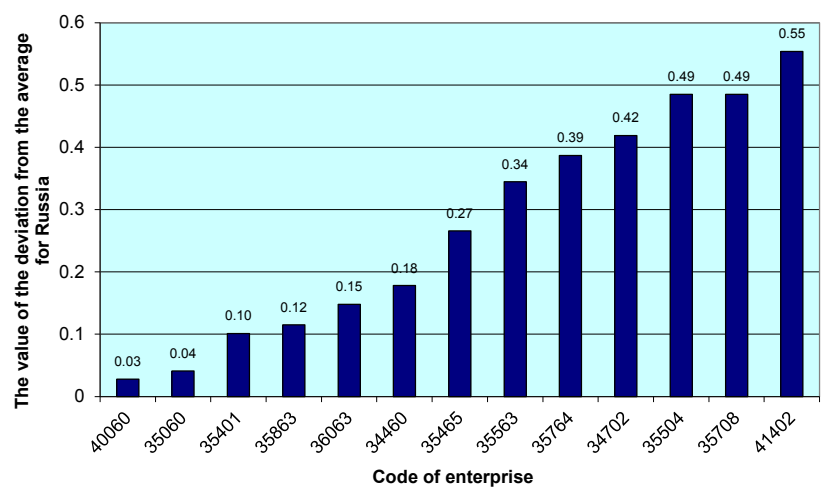

Figure 5: A diagram showing the indicator the level of cars defectiveness during the WM.

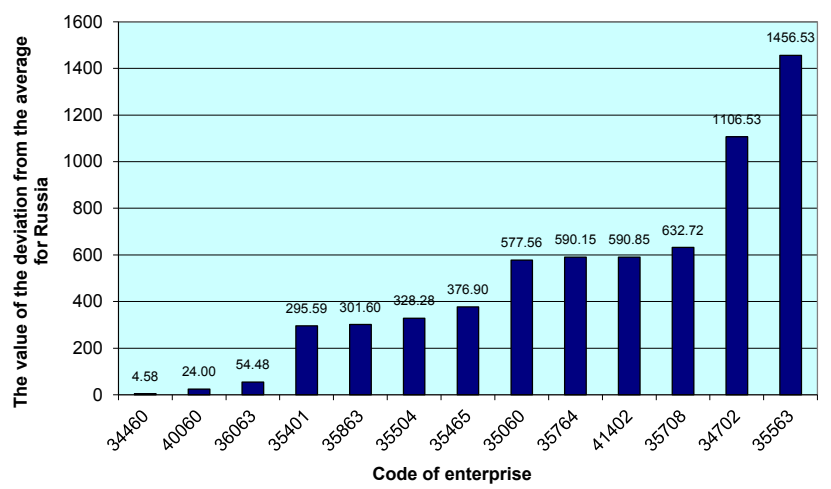

Figure 6: A diagram showing the indicator the level of costs for the elimination of car defects during the period of WM.
There is the diagram in Figure 8 which reflects the indicator distribution of the presence of repeated repairs, when during the WM the same defect is eliminated in the same car two or more times through a short interval of exploitation. That, of course, in the majority of cases shows poor quality of repair or frank violations of service enterprise which are associated with the addition into the warranty act of nonexistent defects (Figure 8).

Analysis of Figure 8 shows that the largest share of repeated repairs in considered group of enterprises is characterized by 41402,34702 services.

\section{Results and Discussion}

Another indicator reflecting the quality of car service during WM is the quality of diagnostic of defects at service enterprise (Figure 9). The basis of the calculation of this indicator is the evaluation of the share of unidentified defects by enterprise personnel during WM.

The worst values of considered indicator (Figure 9) are marked by enterprises 35504,35708 . It can be seen from diagram that the share of unidentified defects is more than $50 \%$. It shows that the competence and qualifications of the technical staff of service enterprises correspond to requirements of proprietary standards.

The joint analysis of diagrams (Figures 5-9) allows distinguishing enterprises with insufficient level of quality of the organization and

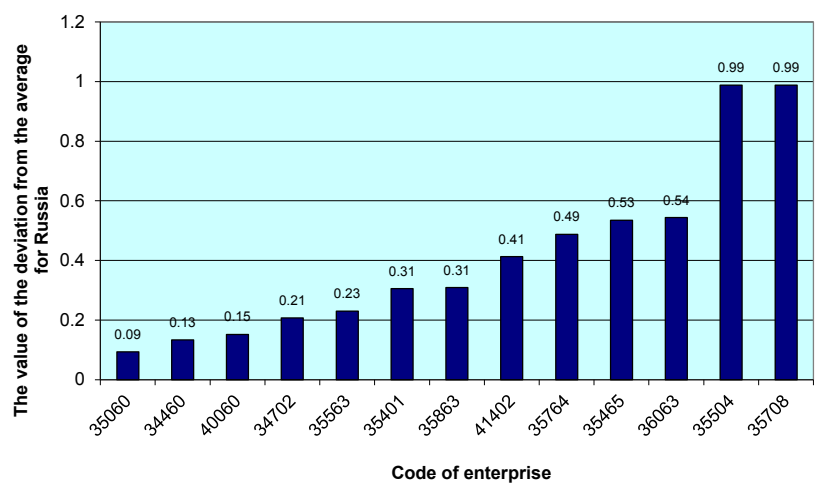

Figure 7: A diagram showing the indicator the completeness of the list of removable defects during the WM.

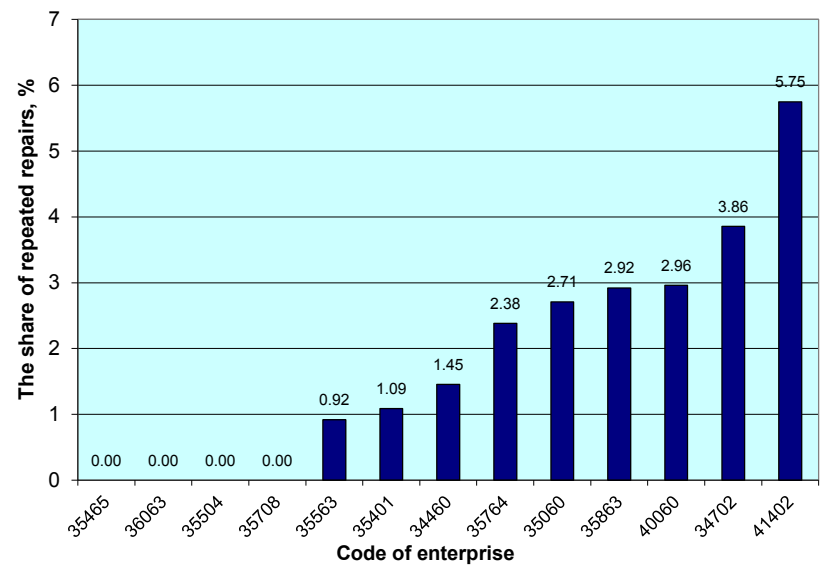

Figure 8: Diagram of indicator distribution of the presence of repeated repairs. 
Citation: Kozlovskiy V, Panyukov D, Odruzova V, Afinogentova N, Ermakov V (2016) The Quality of Automotive Industry: The Remote Monitoring Complex of the Quality of Enterprises Activity of Company Car Service System. J Biosens Bioelectron 7: 223. doi: 10.4172/21556210.1000223

Page 5 of 5

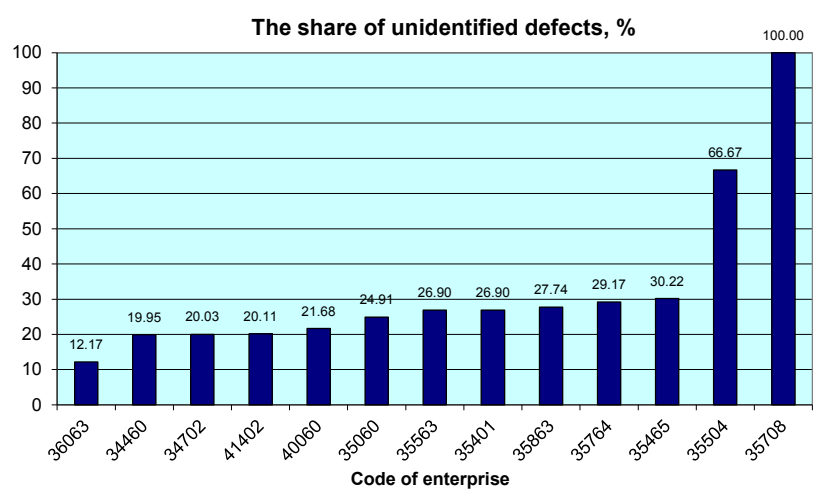

Figure 9: The diagram of distribution of quality diagnostic indicator of defects

execution of works. Besides, the consistent analysis of indicators of antiliders shows that, as a rule, they have fixed «fails» in three or more indicators of quality. It can be taken into account when forming the remarks and work program of inspections. In our case, such enterprises could be 34702,35504 ones.

\section{Conclusion}

In conclusion, it should be noted that proposed remote monitoring complex of the quality of enterprises activity of service network can be formalized within the firm enterprise standard of automaker and realized in the form of a corporate information system of evaluation of activity of enterprises of service network. A list of quality indicators may vary depending on the achievements of the limit of effectiveness in the management of considered indicators and also on promising directions of service development. The monitoring results allow understanding better the occurring in the service network processes, taking into account the objective factors reflecting the actual quality of the product and subjective - reflecting the adding in the PP and WS acts, inappropriate level of competency as an engineering staff and experts diagnosticians, low quality elimination of defects, overvalued level of costs imposed on the automaker acceptance. In this way, level of effectiveness of control for service, which is close to maximum, is being achieved without additional expenses for planning and organizing a large number of inspections, which and to this day is typical for many major automakers.

\section{References}

1. Gonzalez AG (2015) Service Quality and Repurchase Behaviour in the Spanish Automotive After Sales Business. Journal of Relationship Marketing 14 239-267.

2. Ostrom AL, Parasuraman A, Bowen DE, Patricio L, Voss CA (2015) Service Research Priorities in a Rapidly Changing Context. J Serv Res 18: 127-159.

3. Onwuegbuzie AJ, Slate JR, Leech NL, Collins KMT (2009) Mixed Data Analysis: Advanced Integration Techniques. Int J Mult Res Approaches 3: 13-33.

4. Liu C, Rouse WB, Yu Z (2015) When Transformation Fails: Twelve Case Studies in the American Automobile Industry. Journal of Enterprise Transformation 5 71-112.

5. Völckner F, Sattler H, Hennig-Thurau T, Ringle CM (2010) The Role of Parent Brand Quality for Service Brand Extension Success. J Serv Res 13: 379-396.

6. Godlevsky VE, Yunak GL (2005) Quality Management in the Automotive Industry: Monograph. OOO "Etching", CJSC Academic Engineering Center, Samara. p: 628.

7. Kozlovsky VN (2015) New Car Technology Assessment of Competitiveness in Service: Monograph. ANO "Publisher CUP", Samara. p: 158.

8. Szwejczewski M, Goffin K, Anagnostopoulos Z (2015) Product Service Systems, after-sales Service and New Product Development. Int J Prod Res 153: 5334-5353.

9. Sabbagh O, Rahman MNA, Ismail WR, Hussain WMHW (2016) Methodology Implications in Automotive Product-Service Systems: A Systematic Literature Review. Total Quality Management \& Business Excellence.

10. Pluye P, Grad RM, Levine A, Nicolau B (2009) Understanding Divergence of Quantitative and Qualitative Data (or results) in Mixed Methods Studies. International Journal of Multiple Research Approaches 3: 58-72.

11. Qiu RG (2014) Service Science: The Foundations of Service Engineering and Management. p: 336

12. Azman S, Gomiscek B (2014) Functional Form of Connections between Perceived Service Quality, Customer Satisfaction and Customer Loyalty in the Automotive Servicing Industry. Total Quality Management \& Business Excellence 26: 888-904.

13. Dholakia UM, Singh SS, Westbrook RA (2010) Understanding the Effects of Post-Service Experience Surveys on Delay and Acceleration of Customer Purchasing Behavior: Evidence From the Automotive Services Industry. J Serv Res 13: 362-378. 